\title{
New breeding data on Rhinolophus beddomei in Sri Lanka: first record of juveniles
}

\author{
W.G.M. EdIRISINGHE ${ }^{1,2}$, I.M.C. De SiLva ${ }^{2}$, T.G.T. KusumindA ${ }^{2,3}$ \\ M.H.D. Kamindu ThiLina ${ }^{2}$, K.D.S.D. Gunawardana ${ }^{2}$
}

${ }^{1}$ Wild Rescue Team, 183/6, Horana Road, Kesbewa, Piliyandala 10300, Sri Lanka.

2The Young Zoologists' Association, Department of National Zoological Gardens, Dehiwala 10350, Sri Lanka.

${ }^{3}$ Department of Agricultural Biology, Faculty of Agriculture, University of Ruhuna, Mapalana, Kamburupitiya, Sri Lanka.

*Corresponding author: gayan.yza@gmail.com

DOI: https://doi.org/10.14709/BarbJ.9.1.2016.03

Spanish title: Nuevos datos de reproducción en Rhinolophus beddomei en Sri Lanka: primera cita de juveniles.

\begin{abstract}
The lesser woolly horseshoe bat (Rhinolophus beddomei) is a forest dwelling species found throughout Sri Lanka, mostly restricted to old growth forest areas with small populations known, and listed as Vulnerable (VU) according to the National Red List. Two new forest roosting sites of this species were identified in the lowland wet zone within the Mahausakanda and Govinna regions of Sri Lanka's Sabaragamuwa Province and Western Province. Both roosts were found in small caves and were occupied by four individuals of $R$. beddomei including two juveniles in each site. These are the first time two pups per brood recordings of $R$. beddomei in Sri Lanka. Observations were made in April 2012 and March 2015 and it provides evidence that the first quarter of the year might be the breeding cycle of $R$. beddomei. However, the breeding behaviour of this species has not been thoroughly researched and further studies are required on the ecology of this species.
\end{abstract}

Keywords: Breeding, Lesser woolly horseshoe Bat, Rhinolophidae, Rhinolophus beddomei, Caves, Sri Lanka.

\section{INTRODUCTION}

Sri Lanka is a small Indian oceanic island with an area of $65,610 \mathrm{~km}^{2}$ that provides habitats for a rich diversity of mammalian fauna (Yapa \& Ratnavira 2013). Variable geoclimatic features and vegetation structure has generated differing patterns in the distribution of bats in Sri Lanka (Phillips 1935, 1980; Yapa \& Ratnavira 2013). Sri Lankan chiroptera are represented by four species of Old World fruit bats belonging to the Pteropodidae and 26 species of micro-bats belonging to six families: Rhinolophidae, Hipposideridae, Megadermatidae, Molossidae, Vespertilionidae, and Emballonuridae (Bates \& Harrison 1997; Corbet \& Hill 1992). In Sri Lanka, there are two species of Rhinolophidae: Rhinolophus beddomei Anderson, 1905 (Lesser woolly horseshoe bat) and Rhinolophus rouxii Temmink, 1835 (Rufus horse-shoe bat). According to the IUCN Red List, the lesser woolly horseshoe bat is a Least
Concern (LC) species but it is listed as Vulnerable (VU) according to the National Red List of Sri Lanka (Srinivasulu \& Molur 2008; MOE 2012).

Rhinolophus beddomei is a widely-distributed bat species in Sri Lanka (Bates \& Harrison 1997; Menon 2003; Phillips 1935, 1980; Yapa \& Ratnavira 2013). However, it is mostly restricted to old growth forest areas with small populations known. The species range extends from low to mid elevations (43 $\mathrm{m}$ in Kala-Oya and $1,077 \mathrm{~m}$ in Medamahanuwara) (Andersen 1918, Bates \& Harrison 1997). They either live in pairs or in groups of three to four individuals roosting in hollow trees, small caves, abandoned houses, tunnels, culverts, deserted wells or from overhanging rocky outcrops in some isolated forest patches (Phillips 1935, 1980, Yapa \& Ratnavira 2013). In term of reproduction previous studies shows that females may not breed until two or three years of age (Phillips 1935, 1980; Bates \& Harrison 1997). 

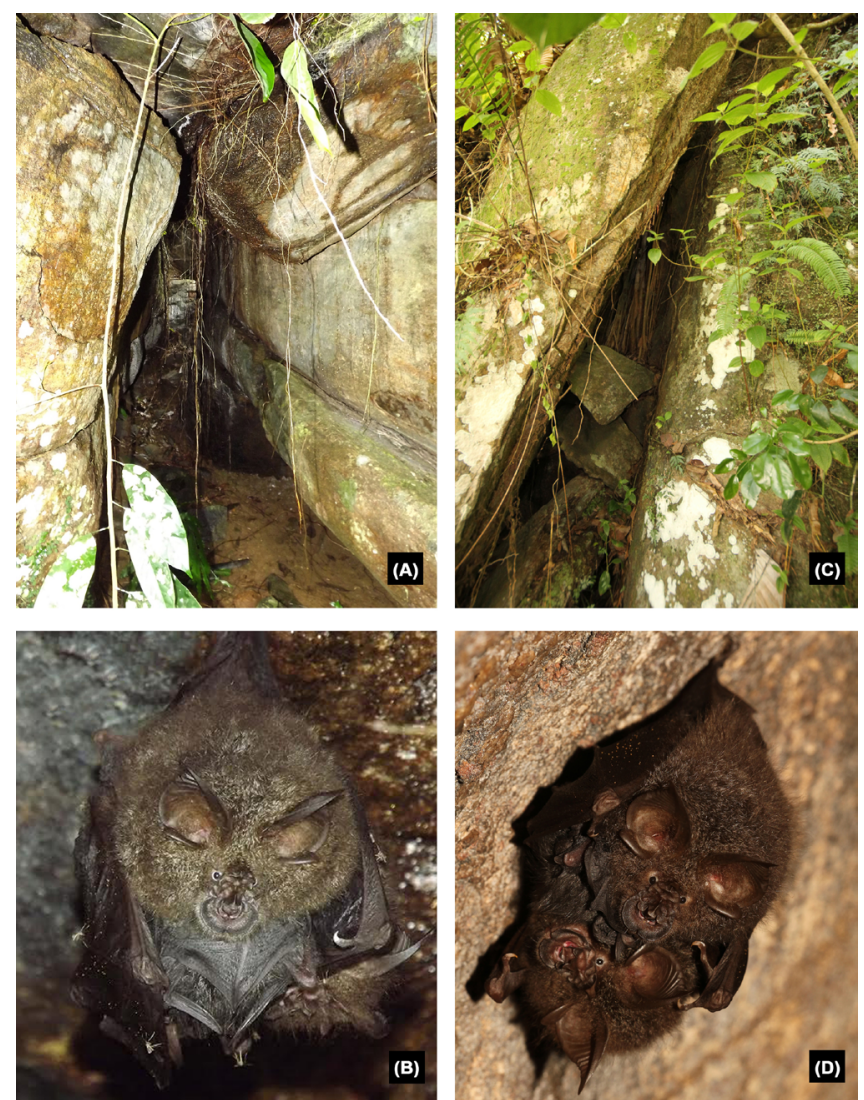

Plate - 1: (A) Roosting place in Mahausakanda Regenerating Rainforest, Kiriella (B) Rhinolophus beddomei roosting with two babies (C) Roosting place in Govinna, Bulathsinhala (D) Rhinolophus beddomei roosting with two babies.

We surveyed bat roosting sites via opportunistic field visits and Visual Encounter Surveys (VES) (Thomas \& LaVal 1988; Thomas et al. 1979). Bat roosting sites were observed during daylight hours with the aid of head lamps using only the red light. Disturbances were kept to a minimum during the observations. Species identification was based upon Phillips (1935) and Bates and Harrison (1997). Magenta Bat 5 heterodyne bat detector was used to locate bats in the second observation site. GPS coordinates of bat roosting sites were taken on site. Phillips (1935) recorded a pregnant female of $R$. beddomei in January (this record did not provide a specific date) in Sri Lanka while a female with a pup was also previously observed in Kerala in Maharashtra (India) on $16^{\text {th }}$ and $22^{\text {nd }}$ May (Brosset 1962).

Our first observation was made on $26^{\text {th }}$ April 2012 in the Mahausakanda regenerated forest $\left(6^{\circ} 76^{\prime} 68.9^{\prime \prime} \mathrm{N}\right.$ and $80^{\circ} 25^{\prime} 38.4^{\prime \prime}$ E), Kiriella, Ratnapura District, Sabaragamuwa Province. This roosting location can be described as an enclosed, humid, small cave $(2.1 \mathrm{~m}$ height, $1.2 \mathrm{~m}$ length and $1.2 \mathrm{~m}$ width) surrounded by an extensive network of rocky outcrops within a relatively undisturbed forest (human activities stopped 10 years ago); the cave was occupied by a group of $R$. beddomei (Figure A). The group was composed two adults and two juveniles; all roosting on the cave ceiling (Figure B). The juveniles had a dense black fur and were clearly at the suckling stage as they were clinging to the female's nipples. Their echolocation was recorded inside the cave (CF calls at 40.3-61.8 kHz).
The second observation was made on $16^{\text {th }}$ March 2015 at Govinna (6 $6^{\circ} 40^{\prime} 01.3^{\prime \prime} \mathrm{N}$ and $\left.80^{\circ} 07^{\prime} 39.9^{\prime \prime} \mathrm{E}\right)$, Bulathsinhala, Kalutara District, Western Province. This roosting site was a partly-eroded, granite rock cave, substantially exposed to sunlight with canopy cover at $40 \%$, and located within a rubber estate (Figure C). This site was occupied by four individuals of $R$. beddome $i$ with two adults and two juveniles (Figure D). The juveniles were clinging onto the females while the adult male was roosting nearby. Their echolocation was recorded inside the cave ( $\mathrm{CF}$ at $41.0-63.5 \mathrm{kHz}$ ).

These observations are from the first half of the year and confirm that this period might be the breeding season for the species. Our study has reported the first juvenile sightings (four individuals in total, two in each group) of $R$. beddomei in Sri Lanka.

Most bats produce only one pup per brood; multiple broods are only found among Vespertilionids although most vesper bats produce a single pup but a significant minority can produce twins and few up to three (Altringham 2011). In the family Rhinolophidae, only one pup per brood has been recorded so far (Phillips 1935; Korad et al. 2010). In contrast, we recorded two pups in a brood of $R$. beddomei in Sri Lanka. Our observations have established the first records for the presence of two individuals in a given brood for this species in Sri Lanka. The brood size of bats can vary due to different reasons. According to Tuttle and Stevenson (1982), older, more experienced females tend to produce larger broods. Myers (1977) found that Eptesicus furinalis generally has two pups in its first annual cycle in Paraguay, but the second litter of the year, when food supplies are diminishing, invariably contains just one pup. The breeding pattern of Rhinilophus rouxil, a related species found in Sri Lanka, is well documented, as opposed to $R$. beddomei. Further studies are required on the reproductive ecology of both species to understand any patterns in brood size.

This study is highlighting the importance of this zone for the bats population, and the need of further development in bat research and monitoring at a local and national level.

\section{ACKNOWLEDgMents}

The author is grateful to Mr. Suranjan Karunarathna and for his help in preparing this paper, to Thilina Surasinghe for editing the manuscript, and Mahesh De Silva and Dinesh Gabadage for field works. Finally, we would like to thank the three anonymous reviewers for useful comments and improvements.

\section{REFERENCES}

Altringham, J.D. 2011. Bats from Evolution to Conservation. Oxford University Press: New York.

Andersen, K. 1918. Diagnoses of new bats of the families Rhinolophidae and Megadermatidae. Ann. Mag. Nat. (Ser.9) 2: 374- 384 . 
Bates, P. J. J. \& Harrison, D. L. 1997. Bats of the Indian Subcontinent. Harrison Zoological Museum: Kent.

Brosset, A. 1962. The bats of central and western India. Part II. Journal Bombay Natural History Society 59: 583624.

Corbet, G. B. \& HiLl, J. E. 1992. The mammals of the Indomalayan Region: a systematic review. Natural History Museum Publications, Oxford University Press: New York.

Korad, V.S., Gailwad, M.C. \& Koratkar, A.L. 2010. Studies on diversity, distribution and habitat preference of bat species in Pune district, Maharashtra. Records of the Zoological Survey of India, 311: 1-52.

Menon, V. 2003. A Field Guide to Indian Mammals, Dorling Kindersley (India) Pvt. Limited: India.

MOE. 2012. The National Red List 2012 of Sri Lanka; Conservation Status of the Fauna and Flora. Ministry of Environment: Colombo.

MYers, P.,1977, Patterns of reproduction of four species of vespertilionid bats in Paraguay. University of California Publications in Zoology, 107: 1-41.

Phillips, W. W. A. 1935. A Manual of the Mammals of Ceylon. Ceylon Journal of Science, London. Dulau \& Company.
Phillips, W. W. A. 1980. Manual of the Mammals of Sri Lanka. Part 1, 2nd Revised Edition. Wildlife and Nature Protection Society of Sri Lanka: Colombo.

Srinivasulu, C. \& Molur, S. 2008. Rhinolophus beddomei. The IUCN Red List of Threatened Species 2008: e.T40023A10306136. http://dx.doi.org/10.2305/IUCN. UK.2008.RLTS.T40023A10306136.en. Downloaded on 16 June 2016.

Thomas, D.W. \& LaVaL, R.K. 1988. Survey and Census Methods. pp. 77-89. In: (Ecological and Behavioral Methods for the Study of Bats: edited by Kunz, T. H.. Smithsonian Institution Press: Washington D. C).

Thomas, D.W., Fenton, M.B. \& Barclay, R.M.R. 1979. Social behavior of the little brown bat, Myotis lucifugus. Mating behavior. Behavioral Ecology and Sociobiology 6(2): 129-136.

TutTle, M.D. \& Stevenson, D. 1982. Growth and survival of bats. pp. 105-150. In: (The Ecology of Bats: edited by Kunz, T.H.: Plenum Press: New York). DOI: http://dx.doi. org/10.1007/978-1-4613-3421-7_3

YAPA. A. \& Ratnavira, G. 2013. The Mammals of Sri Lanka. Field Ornithology Group of Sri Lanka, University of Colombo: Colombo. 